\title{
Okul Öncesi Eğitimde Drama Yöntemi ile İşlenen Değerler Eğitimi Derslerinin Farkındalık Düzeyi Üzerindeki Etkisi
}

\begin{abstract}
Yeliz KAYA Rafet GÜNAY $^{* *}$ Hasan AYDIN ${ }^{* * *}$
Öz

$\mathrm{Bu}$ araştırmanın amacı, değerler eğitiminde drama yönteminin öğrencilerin değerlere ilişkin farkındalıklarını arttırmadaki etkisini saptamaktır. Araştırma kapsamında Diyarbakır il merkezindeki altı farklı anaokulundan 11 okul öncesi öğretmeni ile değerler eğitimi dersi işleyip işlemedikleri, işliyorlarsa nasıl işledikleri ile ilgili görüşme yapılmıştır. Daha sonra bu görüşme bulgularından yola çıkarak değerler eğitimi konularının drama yöntemi ile işlenmesinin etkililiğine dair yarı deneysel bir çalışma yapılmıştır. Bu amaçla bir anaokulunun iki sınıfı deney ve kontrol grubu olarak belirlenmiş ve bu gruplara araştırmacılar tarafından hazırlanan ve uzman görüşü alınarak son şekli verilen Resimli Kartlar Farkındalık Testi uygulanmıştır. Ayrıca deney ve kontrol grubu velilerine araştırmacılar tarafından hazırlanan ve uzman görüşü alınarak son şekli verilen Aile Davranış Değerlendirme Formu uygulanmıştır. Veriler, SPSS 20.0 paket programı ile analiz edilmiş ve drama yöntemi ile işlenen değerler eğitimi dersinin öğrencilerin değerlere ilişkin farkındalıklarını arttırmada etkili olduğu saptanmıştır.
\end{abstract}

Anahtar Kelimeler: Değerler Eğitimi, Drama Yöntemi, Okul öncesi Eğitim.

\section{The Effects Of Values Education Courses Though With}

Drama Techniques in The Student Awareness Levels in

\author{
The Preschool Education
}

\begin{abstract}
The purpose of this study is to determine the effects of drama technique in increasing awareness among preschool children. For this purpose, we first asked to 11 preschool teachers in Diyarbakir to learn whether they thought values in their classes and if they were teaching how they did so. We then conducted a semi experimental study to find out the effectiveness of drama technique for teaching values. For this purpose, we developed a Picture Cards Awareness Test with inputs from experts and implemented the test in two classrooms determined as control and experimental. We also developed a Family Behavior Evaluation Form to measure the views of the parents of the two groups. The collected data was then analyzed in the SPSS 20.0 software program. The results of the study show that drama was an effective technique for teaching values to preschool children.
\end{abstract}

Keywords: Drama Technique, Preschool Education, Value Education.

\footnotetext{
* Doktora Öğrencisi, Yıldız Teknik Üniversitesi, Eğitim Programları ve Öğretim Bölümü, yelizkizmazer@gmail.com

** Doktora Öğrencisi, Yıldız Teknik Üniversitesi, Eğitim Programları ve Öğretim Bölümü, gunay.rafet@gmail.com

${ }^{* * *}$ Yrd. Doç. Dr., Yıldız Teknik Üniversitesi, Eğitim Programları ve Öğretim Bölümü, aydinhytu@gmail.com
} 


\section{GİRIŞ}

Okul öncesi eğitim, çocukların beden, zihin ve duygu yönünden gelişimlerini destekleyerek, onları ilkokula hazırlamakta ve çocukların Türkçeyi doğru ve güzel konuşmalarına yardımcı olmaktadır. Okul öncesi eğitimde çocukların gereksinimlerini karşılamak amacıyla demokratik eğitim anlayışına uygun öğrenme ortamları hazırlanmalı ve öğrenme etkinlikleri hazırlanırken çocukların ilgi ve gereksinimleri göz önünde bulundurulmalıdır (Akman, 1994; Keskin, 2006; Ölçer, 2004; Sevinç, 2004).

Üç yaşla başlayan okul öncesi eğitim süreci, sistemin ilk basamağını oluşturmaktadır. Çocuğun, hazırlanan programla gelişim özelliklerine göre ilkokula hazırlanması amaçlanır. Değerler eğitimi de bu programın bir parçasıdır (Samur, 2011; Uysal, 2008). Okul öncesi dönem, değerlere ilişkin bilgilerin temellerinin atıldığ ilk dönem olarak görülmektedir (Balat ve Dağal, 2009). Çünkü güven, sorumluluk alma, sevgi ve saygı duyma, hakkını koruma, savunma, teşekkür etme, yardım isteme, özür dileme, izin isteme, paylaşma, karar verebilme, problem çözebilme gibi değerler erken yaşlarda kazandırılması gereken değerlerdir. Okul öncesinde değerler eğitimin amacı, çocukların gelişim alanlarının birbiri ile olan dinamik etkileşimini destekleyerek çocuğun bütün gelişim alanlarındaki davranışlarını daha üst düzeye çıkarmak, çeşitlendirmek ve zenginleştirmektir (Yazar ve Erkuş, 2013).

İnsani ve evrensel değerlerin erken yaşta öğretilmesi toplumsal barışın ve oluşan algıların düzelmesine katkı sağlamaktadır. Değerler eğitimi doğru bir şekilde uygulanırsa, çocuğun gelişimine katkı sağlamasının yanı sıra bugün yanlış bilinen birçok saplantılı fikirden de kurtulmuş olunacaktır (Balat ve Beceren, 2010; Gökçek, 2007; Katılmış, Ekşi ve Öztürk, 2011). Diğer taraftan, karakter, benlik ve şahsiyet gibi kavramların yaklaşık \%50'sinin 0-7 yaşları arasında kazanıldığı düşünülecek olursa, okul öncesi dönemde değerler eğitimin nasıl bir önem kazandığı fark edilmiş olacaktır (Keskin ve Söylemez, 2012; Kuczynski ve Kochanska, 1990).

Okul öncesi eğitimde, değerler eğitimi ile ilgili ahlaksal gelişimin desteklenmediği düşünülmektedir. Oysa okul öncesi eğitim kurumları yakından incelendiğinde verilen eğitimin ahlak gelişimini kapsadığı ancak kurumların, ahlaki gelişimin nasıl destekleneceğine dair çok bilgiye sahip olmadığı görülmektedir (Öztürk, 2011). Okul öncesi eğitimde sadece çocukların ilgileri, gereksinimleri, güçlü oldukları yönler, gelişimsel kazanımları değil, aynı zamanda değerleri, inançları ve toplumsal kültürleri de dikkate alınmalıdır (Temel, 2012). Okul öncesi dönemde, çocuklara uygun ortam sağlanması, gerçek hayata yakın oyunlar kurulması ve değişik yöntemlerin sınıf ortamında yürütülmesi mümkündür. Bu tekniklerden birisi drama yöntemi, bir diğeri ise hikâye anlatma yöntemidir.

Drama, içinde hareket, ses, ritim, işbirliği sağlama, duygu ve bilgi alışverişinde bulunma, empati yapma, grupla birlikte hareket etme, kendini grubun bir üyesi olarak görme, başkalarının haklarına saygı gösterme gibi kazanımları barındıran etkili bir öğrenme yöntemidir. Okul öncesi eğitim programı kapsamında çocukların çok yönlü gelişimlerini sağlamak amacıyla birçok etkinliklerin uygulanması gerektiği ve bu etkinliklerin oyun, müzik ve drama olarak çeşitlendirilmesi gerektiği belirtilmektedir (MEB, 2013). Yaparak ve yaşayarak öğrenmeye imkân veren drama yöntemi, çocukların ileriki yaşamlarında karşılaşacakları birçok sorunla baş edebilmelerine yardım edecektir (Yaşar ve Aral, 2011). Dramaya katılan bireyler, drama süresince durumları, olayları, ilişkileri keşfederek öğrenmektedirler. Katılımcılar gerçek dünyadaki bilgi ve deneyimlerini dramada hayali 
bir dünya oluşturmak için kullanmakta ve dramada yapılandırdıkları rolleri tasarlarken olayları ve ilişkileri birbiri arasında bağlantı kurarak incelemeyi öğrenmektedirler ( $\mathrm{O}^{\prime} \mathrm{Neil}$ ve Lambert, 1991). Dramada, farklı rollere girilerek farklı olay ve durumlarla ilgili deneyim kazanma, hayatın algılanmasını ve araştırma isteğinin gelişimini sağlama, yaparak ve yaşayarak öğrenme, öğrenilenlerin kalıcı olması drama çalışmaları sonucunda bireylerde olması beklenen çıktılar arasında görülmektedir (Başkaya, 2000; San, 1996). Bu çıtılar göz önünde bulundurulduğunda dramanın bireylerin gelişiminde önemli bir etkisinin olduğu söylenebilir.

Görüldügüü üzere, okul öncesi dönem, çocukların sosyal ve ahlaki kurallarla ilgili değerleri ve onlarin toplumsal hedeflere uygun bir birey olarak yetişmeleri açısından çok önemlidir. Ancak bu dönemdeki çocukların bu kuralları kazanmaları ile ilgili okul öncesi eğitimin nasıl bir etkisi olduğunu belirleyebilecek çalışmaların da ülkemizde sınırlı olduğu gözlenmektedir (Aslan, 2011; İpşirli, 2011; Öztürk, 2011; Tatar, 2009). Değerler eğitimi ile ilgili araştırmalarda, okul öncesi eğitim ile ilgili araştırmaların yeterince yer almadığı görülmektedir. Bu bağlamda, bu çalışma alandaki araştırmalara temel veri sağlaması açısından önemlidir. Bu araştırmanın amacı, değerler eğitiminde drama yönteminin öğrencilerin değerlere ilişkin farkındalıklarını arttırmadaki etkisini saptamaktır. Bu amaçla değerler eğitiminde drama yönteminin etkililiği öğrenci ve veli bazında irdelenmiştir. Bu çerçevede araştırma soruları;

1. Okul öncesi dönemde değerler eğitimi konuları hangi yöntemlerle işlenmektedir?

2. Değerler eğitiminde drama yöntemi öğrencilerin değerlere ilişkin farkındalıklarını arttırmadaki etkisi nedir? şeklinde belirlenmiştir.

\section{YÖNTEM}

\subsection{Araştırmanın Modeli}

$\mathrm{Bu}$ araştırmada nitel ve nicel araştırma desenlerinin birlikte kullanıldığı karma yöntem araştırmalarından keşfedici sıralı desen kullanılmıştır. Karma yöntem nitel ve nicel araştırma yöntemlerinin birlikte kullanılmasıyla verilerin toplanmasina ve verilerin analiz edilmesine yardımcı olmaktadır (Creswell, 2012). Keşfedici sıralı desende önce nitel veriler toplanır, ardından bu verilerden yola çıkılarak nicel çalışma gerçekleştirilir. (Creswell ve Plano Clark, 2014).

Araştırmanın nitel boyutunda 11 okul öncesi öğretmeni ile değerler eğitimi derslerinin yapılıp yapılmadığ yüze yarı yapılandırılmış görüşme yapılmıştır. Araştırmanın nicel boyutunda ise değerlerin öğretiminde drama yönteminin etkililiğini araştırmak amacıyla deneysel bir çalışma yapılmıştır. Deneysel çalışmanın deseni, gerçek deneme modellerinden öntest-sontest kontrol gruplu yarı deneysel desendir. Gerçek deneme modellerinin gerektirdiği ön koşulların sağlanamadığı durumlarda yarı-deneysel model, kontrol güçlükleri göz önünde bulundurularak sınırlılıklarını dikkate almak koşuluyla uygulanır. Bu modelde, neden - sonuç ilişkisini belirlemek için araştırmacı tarafından kontrol edilen, gözlenmek istenen veriler üretilmektedir (Karasar, 2006). Yapılan öntest sonuçlarına göre gruplar arasında fark olmadığı, her iki grubun birbirine denk olduğu saptanmıştır. $\mathrm{Bu}$ iki grup arasından hangisinin deney, hangisinin kontrol grubu olacağı kura ile belirlenmiştir.

\section{2 Çalışma Grubu}

Araştırmanın nitel boyutunda çalışma grubunu, 2012-2013 eğitim öğretim yılı birinci dönemi süresince devlet okullarında görev yapan 11 okul öncesi öğretmeni oluşturmaktadır. Araştırma kapsamında 6 farklı okulda görev yapan 
11 okul öncesi öğretmeni ile yüz yüze görüşme yapılmıştır. Türkiye'de daha çok bayanların tercih ettiği bir meslek olması dolayısıyla erkek okul öncesi öğretmenine nadiren rastlanmaktadır. Bundan dolayı görüşme yapılan okullardaki okul öncesi öğretmenlerin tamamı bayandır. Okullar ildeki tüm öğretmenleri yansıtması açısından farklı merkez ilçelerden olacak şekilde amaçlı örneklem yöntemiyle seçilmiştir.

Araştırmanın nicel boyutunda 2 çalışma grubu vardır. Birincisi deneysel işlemin uygulandığı öğrenci grubu, diğeri de bu öğrencilerin velileridir. Deneysel işlemin çalışma grubunu 20122013 eğitim öğretim yılı birinci dönemi süresince bir devlet okulunun okul öncesi eğitim kurumuna devam eden 36 tane, 5 yaş grubu çocuk oluşturmaktadır. Okul seçimi, ortalama gelir düzeyine sahip bir mahallede bulunması, eğitim ortamının böyle bir çalışmaya müsait olması ve sınıf öğretmenlerinin bu çalışmaya sıcak bakması kriterleri göz önünde bulundurularak yapılmıştır. Belirlenen okulda 2 tane okul öncesi sınıf bulunmaktadır. Basit raslantısal yöntemle bu sinıflardan birisi deney, diğeri kontrol grubu olarak belirlenmiştir. Deney ve kontrol grubunda başlangıçta 20'şer öğrenci varken, çalışmalar sırasında sağlık nedeniyle kontrol grubundan üç, deney grubundan bir öğrenci derslere düzenli devam edemedikleri için araştırmaya dâhil edilmemiştir. Değerlendirme ve analizler kontrol grubundaki 17 (\%47.2) ve deney grubundaki 19 (\%52.78), toplamda 36 öğrenci üzerinden yapılmıştır. Araştırmanın nicel boyutundaki diğer çalışma grubu da deney ve kontrol gruplarını oluşturan öğrenci velileridir. Bu kapsamda deney grubundan 19, kontrol grubundan 17 olmak üzere toplam 36 veli nicel araştırmanın diğer çalışma grubunu oluşturmaktadır.

\subsection{Veri Toplama Araçları}

\subsubsection{Nicel Veri Toplama Araçları}

Araştırmanın nicel boyutunda iki değiş̧ik veri toplama aracı kullanılmıştır. İlki öğrencilere uygulanan Değerlere İlişkin Resimli Kartlar Testi, ikincisi velilere uygulanan Aile Davranış Değerlendirme Formu'dur. Değerlere İlişkin Resimli Kartlar Testi araştırmacı tarafından geliştirilmiş ve öğrencilerin değerlerle ilgili farkındalık düzeylerini belirlemek amaciyla öntest ve sontest olarak kullanılmıştır. Bu ölçme aracının kapsam geçerliliği için iki iki eğitim bilimleri alanı uzmanı, bir PDR uzmanı ve iki anaokulu öğretmeni olmak üzere toplamda beş uzman görüşü alınmış, verilen dönütler doğrultusunda düzeltmeler yapılarak son şekli verilmiştir. Ölçme aracının güvenirlik çalışmaları sonucunda Cronbach Alpha güvenirlik değerinin ,81 olduğu bulunmuştur. Bu bulguya dayanarak Değerlere İlişkin Resimli Kartlar Testi' nin güvenilir bir ölçme aracı olduğu söylenebilir.

Değerlere İlişkin Resimli Kartlar testi, belirlenen değerlerin olduğu resimlerden oluşan bir testtir. Resimli kartlar sırasıyla öğrencilere gösterilerek kısa hikâye cümleleri eşliğinde öğrencilere resim hakkında bilgi verilmiş ve ardından öğrencilere bu durumla ilgili ne söylenmesi, yapılması gerektiği sorulmuştur. Bu test araştırma öncesinde ve sonrasında öntest-sontest olarak uygulanmıştır. Verilen cevaplar not edilmiş, 1-2-3 puan aralıklarındaki cevaplara göre puanlandırılma yapılmıştır. Testlerin uygulanması 4'er gün sürmüştür.

Araştırma kapsamında ikinci bir ölçme aracı olarak araştırmacı tarafından geliştirilen ve beş uzman görüşü (iki eğitim bilimleri alanı uzmanı, bir PDR uzmanı ve iki anaokulu öğretmeni olmak üzere) alınarak son şekli verilen Aile Davranış Değerlendirme Formu velilere öntest ve sontest olarak uygulanmıştır. Ölçme aracının güvenirlik çalışmaları sonucunda Cronbach Alpha güvenilirlik değeri ,86 olarak bulunmuştur. Bu bulguya dayanarak Aile Davranış Değerlendirme Formu'nun güvenilir bir ölçme aracı 
olduğu söylenebilir. Beşli likert tipinde hazırlanan bu ölçme aracı, araştırma öncesinde ve sonrasinda öntest ve sontest olarak, belirlenen değerlerin var olup olmadığını belirlemek amacıyla aileler tarafından doldurulmuştur. Formda 3 değer yer almakta, saygı değeri için 5 , nezaket ve tutumluluk değerleri için $4^{\prime}$ er madde, toplamda 13 madde yer almaktadir.

\subsubsection{Nitel Veri Toplama Araçları}

Araştırmanın nitel boyutunda okul öncesi öğretmenleri ile yüz yüze görüşme yapılmıştır. $\mathrm{Bu}$ görüşme için iki sorudan oluşan bir form hazırlanmıştır. Hazırlanan görüşme formu için beş uzman (iki eğitim bilimleri alanı uzmanı, bir PDR uzmanı ve iki anaokulu öğretmeni) görüşü alınmış, verilen dönütler doğrultusunda düzeltmeler yapılmıştır. Görüşme formunda değerler eğitimi ile ilgili konuların işlenip

işlenmediği ve işleniyorsa nasıl, hangi yöntemle işlendiğine dair sorular yer almaktadır.

\subsection{Deneysel İşlem}

Araştırma kapsamında belirlenen ilköğretim okulunda iki okul öncesi sınıfı bulunmaktadır. Öncelikle bu sinıflara öntest olarak Değerlere İlişkin Resimli Kartlar Testi uygulanarak grupların eşitliği test edilmiştir. Yapılan test sonucunda her iki sınıfın değerlere ilişkin farkındalık düzeyleri arasında anlamlı bir fark olmadığı anlaşıldığından seçkisiz olarak sınıflardan biri deney, diğeri kontrol grubu olarak atanmıştır. Deney grubuna drama yöntemi ile işlenen değerler eğitimi dersleri uygulanmıştır. Daha sonra sontest olarak Dĕ̆erlere İlişkin Resimli Kartlar Testi tekrar uygulanarak grupların değerlere ilişkin farkındalık düzeyleri analiz edilmiştir. Aşağıda denel işleme ilişkin tablo verilmiştir.

Tablo 1. Deneysel İşlem Deseni

\begin{tabular}{|c|c|c|c|c|}
\hline Grup & & Öntest & Uygulama Süreci & Sontest \\
\hline \multirow[t]{6}{*}{ D (Deney) } & Öğrenci & Değerlere & Drama Yöntemine Göre & Değerlere İlişkin \\
\hline & & Resimli Kartlar Testi & İşlenen Değerler Eğitimi & Resimli \\
\hline & & & Dersi & Testi \\
\hline & Veli & Aile Davranış Değer- & & Davranış \\
\hline & & lendirme Formu & & Değerlendirme \\
\hline & & & & Formu \\
\hline \multirow[t]{6}{*}{ K(Kontrol) } & Öğrenci & Değerlere & & Değerlere İlişkin \\
\hline & & Resimli Kartlar Testi & & Resimli \\
\hline & Veli & Aile Davranış Değer- & & Testi \\
\hline & & lendirme Formu & & Davranış \\
\hline & & & & Değerlendirme \\
\hline & & & & Formu \\
\hline
\end{tabular}

Tablo 1'de görüldüğü gibi deney grubuna ve kontrol grubu öğrencilerine öntest ve sontest olarak Değgerlere İlişkin Resimli Kartlar Testi uygulanmıştır. Deney grubunda drama yöntemine göre değerler eğitimi dersi işlenirken, kontrol grubuna uygulama yapılmamıştır. Ayrıca deney ve kontrol grubundaki öğrencilerin velilerine öntest ve sontest olarak Aile Davranış Değerlendirme Formu uygulanmıştır.
Ana sınıfında öğretilen değerler incelenmiş ve bu araştırma kapsamında 3 değer belirlenmiştir. Değerlerin belirlenmesinde MEB okul öncesi eğitim programı içerisinde yer alan değerler baz alınmıştır. Saygı değeri için 5, nezaket ve tutumluluk değerleri için $4^{\prime}$ er alt başlık belirlenmiştir.

Sayg1

1. Başkalarının eşyalarını kullanırken izin ister. 
2. Ağzında bir şey varken konuşmaz, yemek yerken ağzını şapırdatmaz.

3. Gereken durumlarda sabırla sırasını bekler.

4. Büyüklerine oturmaları için yer verir.

5. Konuşmak için diğerlerinin sözünü bitirmesini bekler.

Nezaket

1. Misafirlere hoş geldiniz der.

2. Bir odaya girmeden önce kapıyı çalar ve gir sesi gelince girer.

3. Başkalarına rahatsızlık verdiğinde özür diler.

4. Kendisine iltifat edildiğinde teşekkür eder.

Tutumluluk

1. Gereksiz yere yanan lambaları kapatır.

2. Oyuncaklarını güzel kullanır, hor kullanmaz.

3. Resim yaparken kâğıt israf etmez.

4. Suyu kullanırken israf etmez ve boşa akan çeşmeleri kapatır.

Araştırma kapsamında deney grubunda drama yöntemi kullanılarak toplamda 13 ders (35'er dakikalık) işlenmiş, kontrol grubunda ise drama yöntemi kullanılmamıştır. Deney grubuna önce drama yaptırılarak değerler işlenmiş, arkasından soru cevap şeklinde yapılan drama etkinlikleri ve işlenen değer hakkında konuşulmuş, son olarak da işlenen değerle ilgili boyama çalışması yaptırılmıştır.

\subsection{Deneyin İç ve Dış Geçerliği}

Deneklerin gruplara yansız atanması deneyin iç geçerliliği açısından önemlidir. Bunun sağlanamadığı durumlarda grupların eşitlenmesi geçerliliği arttırma noktasında oldukça etkili olan bir yöntemdir (Büyüköztürk, Çakmak,
Akgün, Karadeniz ve Demirel, 2010). Bu çalışmada da gruplar yansiz olarak belirlenmese de grupların eşitliği sağlanmıştır. Deneklere verilen testlerin aynı olması ve hem deney hem de kontrol grubuna öntest ve sontesti aynı kişinin uygulaması iç geçerliliği arttıran bir durumdur. Denekler deneysel koşullar ve uygulanacak testlerin farkında değillerdir. Bu durum deneklerin deneysel koşullar hakkında beklenti oluşturmamalarını sağlamakta ve normalden farklı tepki vermelerine engel olduğundan hem iç hem de dış geçerliliğe olumlu yönde katkı sağlamaktadır. Deneysel çalışmada kullanılan testlerin geçerli ve güvenilirliğinin sağlanması, deneyin de geçerlik ve güvenirliğini arttıran bir durumdur. Ayrıca araştırmanın doğal ve gerçek yaşam ortamında yapılması çalışmanın dış geçerliğini arttırmaktadır (Ekiz, 2013).

\section{BULGULAR VE YORUM}

\subsection{Nitel Boyuta İlişkin Bulgular ve Yorum}

Araştırma kapsamında okul öncesi eğitimde değerler eğitimi konularının işlenip işlenmedi$\breve{g} \mathrm{i}$, işleniyorsa nasıl işlendiği araştırılmıştır. Bu amaçla okul öncesi eğitim programı incelenmiş, değerlerle ilgili birtakım kazanımların olduğu görülmüştür. Daha sonra 6 ayrı okuldan 11 anasınıfı öğretmeni ile görüşülmüştür. Bu görüşmeler sonucunda, $\mathrm{MEB}^{\prime}$ in okul öncesi eğitimde zorunlu tuttuğu herhangi bir kaynak kitap olmadığı için, her okulda öğretmenlerin tercihleri doğrultusunda farklı yayınevlerine ait farklı kitapların okutulduğu, sadece bir okulda öğrencilerin alım gücünün düşük olması nedeni ile öğretmenin tercihi doğrultusunda herhangi bir kitap aldırılmadığı ve öğretmenin kendi materyalleri ile ders işlediği tespit edilmiştir.

Ders kitaplarında değerler eğitimi ile ilgili konuların olup olmadığıyla ilgili soruya öğretmenlerin tamamı takip ettikleri kitaplarda 
değerler eğitimi ile ilgili konuların olmadığını veya yeterli bulmadıklarını ifade etmişlerdir. Bazı öğretmenlerin bu konudaki görüşleri şu şekildedir;

"Değgerler eğitimi ile ilgili bazı konular takip ettiğim kitapta var fakat yeterli olduğunu düşünmüyorum. (Öğrt.-3)*

“Öğrencilerle işlediğim kitapta bazı değgerler eğitimi konuları var ama sinırlı. O nedenle bazen hikâye kitaplarından bu konuları okuyarak takviye yapıyorum. (Öğrt.-8).

“Benim yararlandiğım kitapta değerlerle ilgili konular yok. Genellikle değgerlerle ilgili konuları içeren hikâye kitapları var. Onları okuyorum çocuklara. (Öğrt.-2)*

"Benim sınıfımdaki öğrencilerin maddi durumu çok

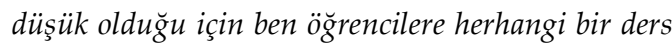
kitabı aldırmadım. Kendi materyallerim var. Onlardan fotokopi çektirip kullanıyorum. (Öğrt.-1)."

Değerler eğitimi konularını hangi yöntemlerle işlediklerine dair soruya ise sadece üç öğretmen bazen drama yöntemini kullandığını ifade etmiştir. Bazı öğretmenlerin bu konudaki düşünceleri şu şekildedir;

"Değerlerle ilgili hikâyeler okuduktan sonra soru cevapla bunu pekiştiriyorum. (Öğrt.-4).”

“Genelde güzel davranışları öğ̈̈tleyen hikâye kitapları var. Onları okuyorum. Bazen de konu ile ilgili drama yaptırıyorum. (Öğrt.-5)."

"Ben genelde bunun için özel olarak herhangi bir şey yapmıyorum. Fakat öğrencimin yanlış yaptı̆̆ı bir davranış olduğunda onu uyarıyor ve nasıl davranması gerektiğini anlatıyorum. (Öğrt.-10).

"Ben öğrencilerin davranışlarında gördüğ̈üm yanlışlıklara anında müdahale ederek doğrusunu anlatıyorum. Bu şekilde öğrencilere değgerleri kazandırmaya çalışıyorum. (Ö̆̆rt.-6).

11 öğretmenle yapılan görüşme sonuçlarından da anlaşılacağı üzere öğretmenler, takip ettikle- ri kitapların değerler eğitimine pek fazla yer vermediğini, sınırlı olarak yer verilen konuları yeterli bulmadıklarını ifade etmişlerdir. Değerlerle ilgili konuları işlerken drama yönteminin az sayıdaki öğretmen tarafindan bazen kullanıldığı, çoğu öğretmenin ise drama yöntemini kullanmadığı anlaşılmaktadır. Öğretmenlerin değerler eğitimi konularını öğrencilere kazandırmak için kullandıkları diğer yöntem ve yolların, hikâye anlatımı, soru cevap, anında uyarma olduğu görülmektedir. Bu bulgulardan yola çıkarak araştırmanın ileri aşamalarında değerler eğitimi konularının okul öncesi öğrencilerine drama yöntemi ile öğretilmesinin etkililiği üzerine deneysel bir çalışma yapılmıştır.

\subsection{Nicel Boyuta İlișkin Bulgular ve Yorum}

$\mathrm{Bu}$ araştırma kapsamında öğrencilere değerlerle ilgili resimli kartlardan oluşan bir test, velilere Aile Davranış Değerlendirme Formu uygulanmış, elde edilen öntest ve sontest puanları SPSS 20.0 paket programı kullanılarak analiz edilmiştir.

Normallik varsayımlarında örneklem sayısı önemlidir (Karasar, 2006). Her bir grupta deney sayısının 30'un altında olduğu durumlarda grupların normal dağılım göstermediği düşünüldügünden parametrik olmayan testler uygulanması tercih edilir (Kabaca ve Erdoğan, 2007). Bu çalışmada deney ve kontrol gruplarındaki öğrenci sayısı 30'un altında olduğundan normal dağılım göstermedikleri varsayılmış ve analizlerde parametrik olmayan testler kullanılmıştır.

Grupların öntest puanları arasında anlamlı bir fark olup olmadığını belirlemek amacıyla deney ve kontrol gruplarının öntestlerine parametrik olmayan testlerden Mann Whitney U Testi uygulanmıştır. Sonuçlar aşağıdaki tabloda verilmiştir. 
Tablo 5. Deney ve Kontrol Grubu Resimli Kartlar Sontest Puanlarının Mann Whitney U Testi Sonucu

\begin{tabular}{|c|c|}
\hline Gruplar & ST \\
\hline Deney & 436.00 \\
\hline Kontrol & 30.00 \\
\hline Deney ve kontrol gruplarının belirlenen değer- & dir. Sonuç olarak drama yöntemi ile \\
\hline lere ilişkin farkındalıklarını ölçmek için ya & dersler sonrasında çocukların belirl \\
\hline sontestin sonuçlarının eşit olup olmadığını & lere ilişkin farkındalıklarında \%51'lik bir artış \\
\hline belirlemek amaciyla yapılan Man Whitney $U$ & olurken, kontrol grubundaki çocuklar \\
\hline testi sonuçları istatistiksel olarak anlamlı bu- & lenen değerlere ilişkin farkındal \\
\hline lunmuştur ( $\mathrm{U}=77 ; \mathrm{p}=.0 ; \mathrm{p}<0.05)$. Bu bulguya & $\% 21^{\prime}$ lik bir artış olmuştur. Bu durumc \\
\hline göre deney ve kontrol grubundaki ço & ler eğitiminde drama yönteminin kull \\
\hline sontestleri arasında belirlenen değerlere ilişkin & nın çok daha etkili bir yöntem olduğ \\
\hline farkındalıklarında anlamlı bir fark vard & bilir. \\
\hline $\begin{array}{l}\text { ortalamaları dikkate alındığında, drama yön- } \\
\text { temi ile değerleri öğrenen çocukların, belirle- } \\
\text { nen değerlere ilişkin farkındalıklarının daha } \\
\text { yüksek olduğu anlaşılmaktadır. Bu bulgu, } \\
\text { değerlerin öğretiminde drama yönteminin } \\
\text { etkili olduğunu göstermektedir. }\end{array}$ & $\begin{array}{l}\text { Deney ve kontrol grubundaki öğrencilerin } \\
\text { ailelerinden uygulama öncesi ve sonrasında } \\
\text { öğrencilerin davranışlarında herhangi bir deği- } \\
\text { şiklik olup olmadığını belirlemek amacıyla Aile } \\
\text { Davramıs Değerlendirme Formu'nu doldurmaları } \\
\text { istenmişti. Bu formlardaki veriler SPSS } 17.00 \text { da }\end{array}$ \\
\hline $\begin{array}{l}\text { Drama yöntemiyle işlenen değerler eğitimi } \\
\text { dersinin ne kadar etkili olduğunu belirlemek } \\
\text { amacıyla deney ve kontrol gruplarının öntest } \\
\text { ve sontest ortalamaları arasındaki artışa bakıl- }\end{array}$ & $\begin{array}{l}\text { çözümlemiştir. Uygulama öncesinde Aile Dav- } \\
\text { ranış Değerlendirme Formundan elde edilen } \\
\text { veriler öntest, uygulama sonrasında elde edilen } \\
\text { veriler sontest olarak değerlendirilecektir. }\end{array}$ \\
\hline $\begin{array}{l}\text { mıştır. Deney grubunun öntest ortalaması } 0.36 \text {, } \\
\text { sontest ortalaması } 0.87 \text { olarak bulunmuştur. } \\
\text { Arada sontest puanı lehine \% } 51^{\prime} l i k \text { bir artış } \\
\text { vardır. Kontrol grubunun öntest ortalaması } \\
0.38 \text {, sontest ortalaması } 0.59 \text { olarak bulunmuş- } \\
\text { tur. Arada sontest lehine } \% 21^{\prime} \text { lik bir artış var- }\end{array}$ & $\begin{array}{l}\text { Grupların öntest puanları arasında anlamlı bir } \\
\text { fark olup olmadığını belirlemek amacıyla de- } \\
\text { ney ve kontrol gruplarındaki çocukların velile- } \\
\text { rinin öntestlerine parametrik olmayan testler- } \\
\text { den Mann Whitney U Testi uygulanmıştır. } \\
\text { Sonuçlar aşağıdaki tabloda verilmiştir. }\end{array}$ \\
\hline
\end{tabular}

Tablo 6. Deney ve Kontrol Grubu Aile Davranış Değerlendirme Formu Öntest Puanlarının Mann Whitney

U Testi Sonucu

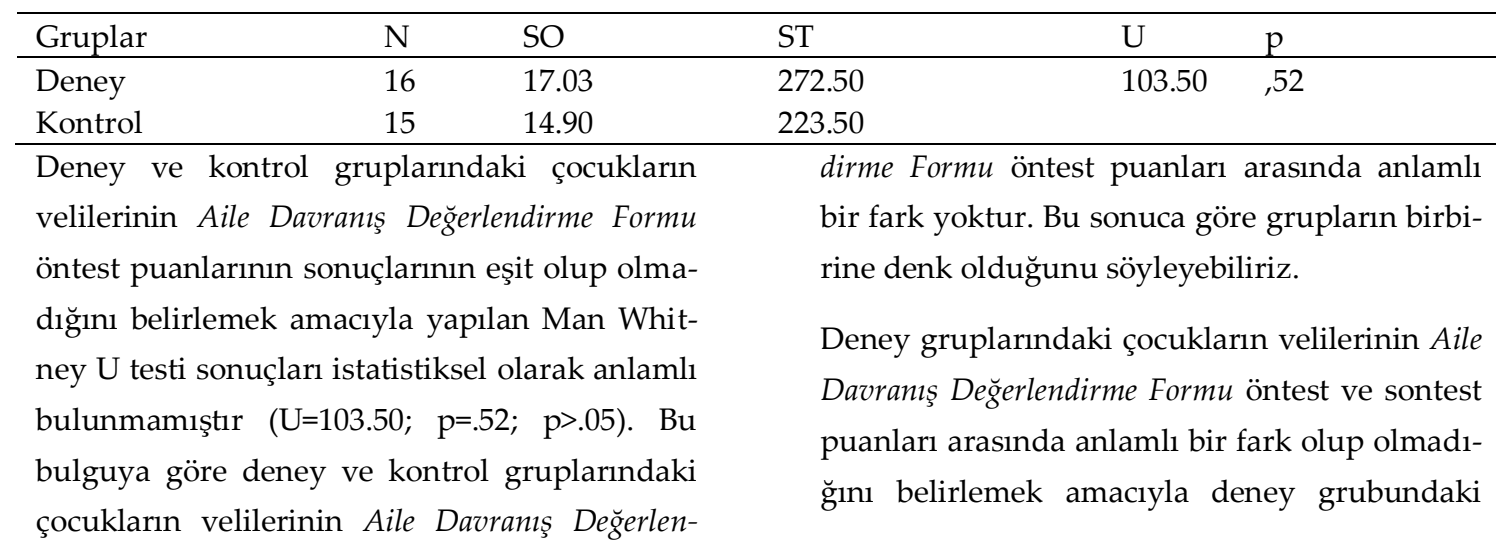


çocukların velilerinin öntest ve sontestlerine

uygulanmıştır. Sonuçlar aşağıdaki tabloda parametrik olmayan testlerden Wilcoxon Testi

verilmiştir.

Tablo 7. Deney Grubu Aile Davranış Değerlendirme Formu Öntest-Sontest Puanlarının Wilcoxon Testi Sonuçları

\begin{tabular}{llllll}
\hline Öntest-Sontest & $\mathrm{N}$ & $\mathrm{SO}$ & $\mathrm{ST}$ & $\mathrm{Z}$ & $\mathrm{p}$ \\
\hline Negatif Sıra & 4 & 5.50 & 22.00 & -2.16 & .031 \\
Pozitif Sıra & 11 & 8.91 & 91.00 & & \\
Eşit & 1 & - & & & \\
\hline
\end{tabular}

Deney grubundaki çocukların velilerinin uygurülmektedir. Bu sonuçlara göre drama yöntemi lama öncesi ve sonrası değerlere ilişkin çocukile öğretilen değerlerin çocuklar üzerinde larının davranışlarında anlamlı bir farklılık olup olmadığına ilişkin yapılan Wilcoxon testi sonucunda, deney grubundaki çocukların velilerinin Aile Davranış Değerlendirme Formu öntest ve sontest puanları arasında anlamlı bir fark olduğunu görülmektedir $(\mathrm{Z}=2.16 ; \mathrm{p}=.03 ; \mathrm{p}<.05)$. Fark puanlarının sira ortalaması ve toplamları dikkate alındığında, gözlenen bu farkın pozitif sıralar, yani sontest puanı lehine olduğu göolumlu yönde bir davranış değişikliğine yol açtı̆̆ı söylenebilir.

Kontrol grubundaki çocukların velilerinin Aile Davranış Değerlendirme Formu öntest ve sontest puanları arasında anlamlı bir fark olup olmad1ğını belirlemek amaciyla kontrol grubunun öntest ve sontestlerine parametrik olmayan testlerden Wilcoxon Testi uygulanmıştır. Sonuçlar aşağıdaki tabloda verilmiştir.

Tablo 8. Kontrol Grubu Aile Davranış Değerlendirme Formu Öntest-Sontest Puanlarının Wilcoxon Testi Sonuçları

\begin{tabular}{llllll}
\hline Öntest-Sontest & $\mathrm{N}$ & $\mathrm{SO}$ & $\mathrm{ST}$ & $\mathrm{Z}$ & $\mathrm{p}$ \\
\hline Negatif Sıra & 7 & 6.64 & 46.50 & -.377 &, 706 \\
Pozitif Sıra & 7 & 8.36 & 58.50 & & \\
Eşit & 1 & - & & & \\
\hline
\end{tabular}

Kontrol grubundaki öğrencilerin velilerinin uygulama öncesi ve sonrası çocuklarının değerlere ilişkin farkındalık düzeylerinin anlamlı bir değişiklik gösterip göstermediğine ilişkin yapılan Wilcoxon testi sonuçlarl, kontrol grubundaki çocukların velilerinin Aile Davranış Değerlendirme Formu öntest ve sontest puanları arasinda anlamlı bir fark olmadığını göstermekte$\operatorname{dir}(\mathrm{z}=-.377 ; \mathrm{p}=.706 ; \mathrm{p}>.05)$. Bu sonuçlara göre kontrol grubundaki çocukların davranışlarında herhangi bir değişiklik oluşmadığı söylenebilir.

Grupların Aile Davranış Değerlendirme Formu sontest puanları arasında anlamlı bir fark olup olmadığını belirlemek amacıyla deney ve kontrol gruplarının sontestlerine parametrik olmayan testlerden Mann Whitney U Testi uygulanmıştır. Sonuçlar aşağıdaki tabloda verilmiştir.

Tablo 9. Deney ve Kontrol Grubu Aile Davranış Değerlendirme Formu Sontest Puanlarının Mann Whitney U Testi Sonucu

\begin{tabular}{llllll}
\hline Gruplar & $\mathrm{N}$ & $\mathrm{SO}$ & $\mathrm{ST}$ & $\mathrm{U}$ & $\mathrm{p}$ \\
\hline Deney & 16 & 19.16 & 306.50 & 69.50 &, 046 \\
Kontrol & 15 & 12.63 & 189.50 & & \\
\hline \multicolumn{2}{c}{$\begin{array}{l}\text { Deney ve kontrol grupları velilerinin Aile Dav- } \\
\text { ranış Değerlendirme }\end{array}$} & Formu & öntest puanlarının & sonuçlarının eşit & olup olmadığını belirlemek \\
&
\end{tabular}


rı istatistiksel olarak anlamlı bulunmuştur $(\mathrm{U}=69.50 ; \mathrm{p}=.046 ; \mathrm{p}<.05)$. Bu bulguya göre deney ve kontrol grubundaki çocukların velilerinin Aile Davranış Değerlendirme Formu sontest puanları arasında anlamlı bir fark vardır. Sıra ortalamaları dikkate alındığında, drama yöntemi ile değerleri öğrenen çocukların daha olumlu yönde bir davranış değişikliği gösterdikleri anlaşılmaktadır. Bu bulgu, değerlerin öğretiminde drama yönteminin olumlu davranış değişikliği meydana getirmede daha etkili olduğunu göstermektedir.

\section{TARTIŞMA VE SONUÇ}

Drama yöntemi ile işlenen değerler eğitimi dersinin öğrencilerin farkındalıklarında herhangi bir değişikliğe yol açıp açmadığını belirlemeye ilişkin yapılan bu deneysel çalışmada araştırmacılar tarafından geliştirilen "Resimli Kart Testi" ve "Aile Davranış Değerlendirme Formu" kullanılmıştır.

Araştırma kapsamında belirlenen değerler eğitimi konuları deney grubuna drama yöntemi ile öğretilmiştir. Yapılan analizlerde hem deney hem de kontrol grubunda öğrencilerin işlenen değerlerle ilgili farkındalıklarının artı̆ğ tespit edilmiştir. Ayrıca deney ve kontrol gruplarının sontestleri arasında anlamlı bir fark olup olmadığını anlamak için yapılan Man Whitney U testi sonucuna göre gruplar arasında deney grubu lehine bir fark saptanmıştır. Yani drama yönteminin daha etkili olduğu görülmektedir. Drama yönteminin ne kadar etkili olduğunu analiz etmek için deney ve kontrol gruplarının öntest ve sontest ortalamalarına bakılmıştır. Deney grubunun öntest ortalaması 0.36 , sontest ortalaması 0.87 olarak bulunmuştur. Arada sontest puanı lehine \%51'lik bir artış vardır. Kontrol grubunun öntest ortalaması 0.38 , sontest ortalaması 0.59 olarak bulunmuştur. Arada sontest lehine \%21'lik bir artış vardır. Sonuç olarak drama yöntemi ile işlenen dersler sonrasında çocukların belirlenen değerlere ilişkin farkındalıklarında \%51'lik bir artış olurken, kontrol grubunda çocukların belirlenen değerlere ilişkin farkındalıklarında \%21'lik bir artış olmuştur. $\mathrm{Bu}$ durumda değerler eğitiminde drama yönteminin kullanılmasının oldukça etkili bir yöntem olduğu söylenebilir.

Drama yönteminin etkililiğine dair yapılmış pek çok araştırma mevcuttur (Candaş, 2008; Doğan, 2004; Kamen, 1992; Kocayörük, 2000; Pantidos, Spathi \& Vitoratos, 2001; Oğur \& Kılıç, 2004; Selvi, 2003). Cömertpay (2006) tarafından okul öncesi eğitimde yaratıcı drama etkinliklerinin 5-6 yaş grubu çocuklarının dil edinimine etkisini araştırmak için yapılan araştırmada, yaratıcı drama etkinliklerinin çocukların kullandıkları ad öbeği sayısını artırdı̆̆ı belirlenmiştir. Yine Akınoğlu ve Akbaş'ın (2010) yaptığı araştırmada da problem çözme stratejisi olarak drama uygulamalarının kavram öğrenmede daha etkili olduğu görülmüştür. Yalım’ın (2009) okulöncesi eğitimi alan 5-6 yaş çocuklarında matematiksel şekil algısı ve sayı kavramının gelişiminde drama yönteminin etkisini incelediği deneysel çalışmada, çocukların geometrik şekil ve sayı kavramlarını kazanmalarında drama yönteminin önemli derecede etkisi olduğunu saptamıştır.

Eğitim çalışmalarında dramanın aktif olarak kullanılması, öğrencilerin çok yönlü gelişmelerini sağlar, özellikle ahlaki gelişimde ve öğrencilere ahlaki değerlerin kazandırılmasında çok etkili ve önemlidir. Öğrencilerin hoşgörülü, birbirini anlayan, empati yapabilen, saygilı bireyler olarak yetişmeleri, drama çalışmalarının temel hedeflerindendir (Topbaşı, 2006).

Öğretilen değerlerin öğrenci davranışlarında herhangi bir değişiklik meydana getirip getirmediğini anlamak amaciyla deney ve kontrol grubu öğrencilerinin velilerine uygulanan 
“Aile Davranış Değerlendirme Formu" verilerinin analizi sonucunda, deney grubu öntest ve sontestleri arasında sontest lehine anlamlı bir fark olduğu görülmüştür. Yani deney grubundaki aileler, drama yöntemi ile öğretilen değerlerin öğrenci davranışlarında olumlu yönde bir değişiklik meydana getirdiğini belirtmişlerdir. Kontrol grubu öntest ve sontestlerine yapilan analizler sonucunda gruplar arasinda anlamlı bir fark olmadığı görülmüştür. Yani kontrol grubundaki aileler, öğrencinin davranışlarında herhangi bir değişiklik meydana gelmediğini belirtmektedir.

Son olarak deney ve kontrol gruplarının sontestleri arasında anlamlı bir fark olup almad1ğını anlamak için Mann Whitney U Testi uygulanmıştır. Bu test sonucunda gruplar arasında deney grubu lehine anlamlı bir fark olduğu görülmüştür. Yani aileler de drama yöntemiyle işlenen değerlerin, öğrencilere değerlere ilişkin davranışların kazandırılmasında daha etkili olduğunu ifade etmektedirler.

"Resimli Kartlar Testi" ve "Aile Davranış Değerlendirme Formu" test sonuçlarından anlaşılacağı gibi drama yönteminin değerlere ilişkin farkındalık düzeyini arttırmada okul öncesi çocukları üzerinde çok daha etkili olduğu görülmektedir. Okul öncesi değerler eğitiminde hikâye anlatımı, değere ilişkin resim göstererek soru sorma gibi yöntemler daha az uğraşı gerektirdiğinden dolayı daha yaygın olarak kullanılsa da drama yöntemi ile işlenen dersler hem farkındalık oluşturmada hem de davranış değişikliği meydana getirmede daha etkili olmaktadır. Bu nedenle okul öncesi öğretmenleri değerler eğitiminin öğretiminde drama yöntemini kullanmaları için teşvik edilmelidir.

\section{Kaynakça}

Akınoğlu, O., ve Akbaş, H. Ş. (2010). Fen Eğitiminde Problem Çözme Stratejisi Olarak Drama Uygulamalarının Kavramsal Anlamaya Etkisi. International Conference on New Trends in Education and Their Implications. Antalya-Turkey, 360-366.

Akman, B. (1994). Okul Öncesi Dönemde Ahlak (Moral) Gelişimi, Okul Öncesi Eğitimcileri için El Kitabı, (Editör: Şule Bilir). İstanbul: Ya-Pa Yayınları.

Aslan, M. (2011). İlköğretimde Karakter Eğitimi ve Öğrencilere Kazandırılması Gereken Değerler. Yayınlanmamış Yüksek Lisans Tezi. Eskişehir Osmangazi Üniversitesi, Eskişehir.

Balat, G. U., ve Beceren, B. Ö. (2010). Okul Öncesi Dönemde Değerler Eğitimi. Eğitime Bakış Dergisi. 18(6), 59-63.

Balat, G.U., ve Dağal, A.B. (2009). Okul Öncesi Dönemde Değerler Eğitimi Etkinlikleri. Ankara: Kök Yayınc1lik.

Başkaya, Ö. (2000). Dört Drama Liderinin Yaklaşımlarına Genel Bir Bakış ve Yaratıcı Dramada Temel İlkeler. Türkiye 2. Drama Liderler Buluşması. Yayına Hazırlayan: Naci Aslan. Ankara: Oluşum Tiyatrosu ve Drama Atölyesi. 83-88.

Büyüköztürk, Ş., Çakmak, E., Akgün, Ö.E., Karadeniz, Ş. ve Demirel, F. (2010). Bilimsel Araştırma Yöntemleri, Ankara: Pegem Akademi.

Can-Yaşar, M. ve Aral, N. (2011). Türkiye'de Okul Öncesinde Drama Alanında Yapılan Lisansüstü Tezlerin İncelenmesi. Mehmet Akif Ersoy Üniversitesi Ĕ̆itim Fakültesi Dergisi, 22, 75-96. 
Candaş, C. (3 Mayıs 2004). Etkili Bir Öğretim Yöntemi: Yaratıcı Drama. Eğitimde İyi Örnekler Konferansı. http://www.egitimdeiyiornekler.org/assets/gecmis-iokler/.pdf adresinden erişilmiştir

Cömertpay, Binnur. (2006). Dramanın 5-6 Yaş Grubu Çocuklarının Dil Edinimine Etkisi. Yayınlanmamış Doktora Tezi. Çukurova Üniversitesi, Adana.

Creswell, John. (2012). Educational Research: Planning, Conducting, and Evaluating Quantitative and Qualitative Research. Saddle River, NJ: Prentice Hall.

Creswell, J., ve Plano Clark, V. L. (2014). Karma Yöntem Araştırmaları (Çeviri Ed. Dede,Y. ve Demir S.B.) Ankara: Anı Yayıncilı.

Doğan, M. (3 Mayıs 2004). Biyoloji Derslerinde Yaratıcı Drama ile Öğrenmeye Örnekler. Eğitimde İyi Örnekler Konferansı, İstanbul.

Ekiz, D. (2013). Bilimsel Araştırma Yöntemleri. Ankara: Anı Yayıncılık.

Gökçek, S. (2007). 5-6 Yaş Çocukları İçin Hazırlanan Karakter Eğitimi Programının İncelenmesi. Yayınlanmamış Yüksek Lisans Tezi. Marmara Üniversitesi, İstanbul.

İpşirli, S. (2011). 3-6 Yaş Çocuğun Genel ve Din Eğitiminde Temel Değerler. Yayınlanmamış Yüksek Lisans Tezi. Marmara Üniversitesi, İstanbul.

Kabaca, T. ve Erdoğan, Y. (2007). Fen Bilimleri, Bilgisayar ve Matematik Eğitimi Alanlarındaki Tez Çalışmalarının İstatistiksel Açıdan İncelenmesi. Pamukkale Üniversitesi Eğitim Fakültesi Dergisi. 2,(22), $54-63$.

Kamen, M. (1992). Creative Drama and the Enhancement of Elementary School Students' Understanding of Science Concepts. Dissertation Abstracts International, DAI-A 52(07), 2489.

Karasar, Niyazi. (2006). Bilimsel Araştırma Yöntemi. Ankara: Nobel Yayınları.

Katılmış, A., Ekşi, H. ve Öztürk, C. (2011). Sosyal Bilgiler Ders Kazanımlarıyla Bütünleştirilmiş Karakter Eğitimi Programının Etkililiği - Efficiency of Social Studies Integrated Character Education Program. Kuramdan Uygulamada Ĕ̆itim Bilimleri Dergisi (KUYEB), 2(11), 530-548.

Keskin, E. (2006). Okul Öncesi Eğitim Öğretmenlerinin Öz-Yeterlik Düzeyleri İle Problem Çözme Yaklaşımlarını Kullanma Düzeyleri Arasındaki İlişkinin İncelemesi (Denizli İli Örneği). Yayınlanmamış Yüksek Lisans Tezi. Pamukkale Üniversitesi, Denizli.

Keskin, S.C. ve Söylemez, H. (16-18 Kasım 2012). Değer Eğitimine Dair Okul Aile İşbirliğinde Veliler Eğitimin Neresinde?, II. Uluslararası Değerler Sempozyumu Bildirisi, İstanbul.

Kocayörük, A. (2000). İlköğretim Öğrencilerinin Sosyal Becerilerini Geliştirmede Dramanın Etkisi. Yayınlanmamış Yüksek Lisans Tezi. Ankara Üniversitesi, Ankara.

Kuczynski, L. ve Kochanska, G. (1990). Development of Children's Noncompliance Strategies From Toddlerhood to Age 5. Developmental Psychology 26, 398-408.

MEB. (2013). Okul öncesi Ĕ̆itimi Programı. http://tegm.meb.gov.tr/dosya/okuloncesi/ooproram.pdf adresinden erişilmiştir.

Oğur, B. ve Kılıç, G.B. (9-11 Ekim 2004). Canlıların İç Yapısına Yolculuk ve Vücudumuzda Neler Var? Çevremizi Nasıl Algılıyoruz? Ünitelerinde Yaratıcı Drama Uygulaması, 6.Ulusal Fen Bilimleri ve Matematik Ĕ̆itimi Kongresi, 71. İstanbul. 
O’Neil, C. ve Lambert, A. (1991). Drama Structures A Pratical Handbook for Teachers. Chelpenman: Heinemann Educational Books.

Ölçer, S. (3 Mayıs 2004). Okul Öncesinde Fen-Doğa Matematik Materyalleri, Poster Bildiri, Ĕ̆itimde İyi Örnekler Konferansı, İstanbul: Sabancı Üniversitesi.

Öztürk, N. (2011). 61-72 Aylık Çocuklar İçin Ahlaki Değer Yapısını Belirleme Ölçeği'nin Geçerlik ve Güvenirlik Çalışması (Ankara Örneklemi). Yayınlanmamış Yüksek Lisans Tezi. Gazi Üniversitesi, Ankara.

Pantidos, P., Spathi, K. ve Vitoratos, E. (2001). The Use of Drama in Science Education: The Case of Blegdamsvej Faust. Science and Education, http://www.ingentaconnect.com/adresinden erişilmiştir.

Samur, A. Ö. (2011). Değerler Ĕ̆itimi Programının 6 Yaş Çocuklarının Sosyal ve Duygusal Gelişimlerine Etkisi. Yayınlanmamış Doktora Tezi. Selçuk Üniversitesi, Konya.

San, İ. (1996). Yaratıcılığı Geliştiren Bir Yöntem ve Yaratıcı Bireyi Yetiştirme Bir Disiplin: Eğitsel Yaratıcı Drama. Yeni Türkiye Dergisi, 7, 148-160.

Selvi, K. (2003). Eğitimde Yaratıcı Drama Yöntemini Uygulama İkeleri, Anadolu Üniversitesi Ĕ̆itim Fakültesi Dergisi, 13(2), 181-188.

Sevinç, M. (2004). Erken Çocuklukta Gelişim ve Ĕ̆itimde Yeni Yaklaşımlar. İstanbul: Morpa Yayınevi.

Tatar, A.F. (2009). Okul Öncesi Eğitiminde (5-6 Yaş) Hoşgörü Eğitimi. Yayınlanmamış Yüksek Lisans Tezi. Ankara Üniversitesi, Ankara.

Topbaşı, F. (2006). Okul Öncesi Dönem 6 Yaş Grubu Çocukların Törel (Ahlâkî) Gelişiminde Dramanın Yeri ve Önemi. Yayınlanmamış Yüksek Lisans Tezi. Ankara Üniversitesi, Ankara.

Uysal, F. (2011). Karakter Eğitim Programlarının Değerlendirilmesi. Yayınlanmamış Yüksek Lisans Tezi. Yeditepe Üniversitesi, İstanbul.

Yalım, N. (2009). 5-6 Yaş Çocuklarında Matematiksel Şekil Algısı Ve Sayı Kavramının Gelişiminde Drama Yönteminin Etkisi. Yayınlanmamış Yüksek Lisans Tezi. Selçuk Üniversitesi, Konya.

Yazar, T. ve Erkuş, S. (2013). The Evaluation the Opinions of Pre-school Education Teachers About the Values Education in Pre-school Education Programme. Dicle Üniversitesi Ziya Gökalp Eğitim Fakültesi Dergisi, 20, 196-211. 


\section{Extended Summary}

The pre-school period, is of vital importance on account of the manner in which it sets down the basis for the child's future. During this period, great importance is attached to the issue of the teaching of principle human and moral values. A child who adopts the necessary values during this period, will apply what he or she has learnt from these lessons throughout the whole of their lives providing they do not encounter situations in which these values are not excessively assaulted or shaken. In pre-school educational institutions various methods are applied in the teaching of values including: question and answer sessions, educational games, story telling and drama activities.

The purpose of this study is to determine the effect of the drama method employed within the context of values education on the raising of awareness of students with regard to the values presented within this education. Within the scope of this study, interviews with 11 pre-school teachers at six different kindergartens were conducted to discover whether or not values education lessons were conducted, and in cases where they were given, how exactly they were delivered. After this stage, proceeding from the findings of these interviews, a semi-experimental study was conducted with regard to the effectiveness of the drama method in the teaching of the subject content of values education. With this aim in mind, two classes at one kindergarten were designated as the experimental and control groups, and after eliciting the opinions of experts in the field, an awareness test using illustrated cards was designed and applied in the respective classes by the researchers. Moreover, a familial behavior evaluation form was then designed and applied in accordance with the data obtained from the experimental and control groups and after consultation with experts in the field.. The data obtained was then analyzed using SPSS 20.00 software and it was established that the drama method was effective in raising student awareness with regard to the values contained within applied values education programs.

According to the results of the study, pre-school teachers rarely employ the drama method as a component part of the teaching of topics contained within values education In general these the teaching of these subjects are conducted using story- telling and question-answer techniques. Furthermore, teachers expressed the view that there was a lack of values-related topics in the books presently used. The results of the study support the view that the drama method is extremely effective in the teaching of the subjects contained within the values education program. It was observed that in the class in which the drama method was used, students' awareness of values-related topics was much higher than that of their peers in the control group. Furthermore, study attempted to establish the degree to which students in the experimental and control groups reflected what that had learned in school in the home environment with their families; the parents of those in the experimental group expressed that they observed much improved behaviors on the part of their children as regards the issue of the values they displayed. The results of the study strongly support the view that the drama method is extremely effective both in the teaching of values-education subject matter and on observation of students' behaviors (to influence these in a positive fashion). 